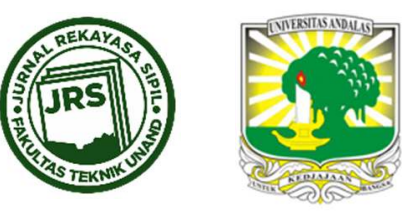

\title{
EVALUASI KETERSEDIAAN AIR DAS DELI TERHADAP KEBUTUHAN AIR (WATER BALANCED)
}

\author{
MIZANUDDIN SITOMPUL ${ }^{1} \&$ RIZKI EFRIDA ${ }^{2}$ \\ ${ }^{1}$ Universitas Muhammadiyah Sumatera Utara ( $\triangle$ mizanuddins@gmail.com) \\ ${ }^{2}$ Universitas Muhammadiyah Sumatera Utara (rizki.efrida@gmail.com)
}

\begin{abstract}
Kebutuhan akan sumber daya air pada saat ini cenderung mengalami peningkatan seiring dengan bertambahnya jumlah penduduk dan perkembangan pembangunan industri. Hal ini menyebabkan terjadinya ketidakseimbangan dalam memenuhi kebutuhan di sektor pertanian dan kebutuhan air baku. Daerah Aliran Sungai Deli adalah salah satu sumber daya air yang digunakan untuk memenuhi kebutuhan air di Daerah Irigasi Namorambe dan kebutuhan air baku domestik dan non domestik di Kabupaten Deli Serdang dan Kota Medan. Penelitian ini bertujuan untuk mengevaluasi neraca air yaitu jumlah ketersediaan air dengan kebutuhan air di DAS Deli yang didasarkan kepada jumlah alokasi air. Penelitian ini mempunyai 3 tujuan khusus yaitu menganalisis ketersediaan air di DAS Deli, menganalisis kebutuhan air di DAS Deli, dan mengevaluasi neraca air antara ketersediaan air dengan kebutuhan air di masa mendatang. Data yang diperlukan dalam penelitian ini adalah data curah hujan bulanan dengan klimatologi, jumlah penduduk, kebutuhan air Daerah Irigasi Namorambe, dan alokasi air di DAS Deli. Data curah hujan dan klimatologi digunakan sebagai analisis data ketersediaan air di DAS Deli sementara jumlah penduduk dan data kebutuhan air irigasi dianalisis untuk menghitung jumlah kebutuhan air yang memanfaatkan air dari DAS Deli. Hasil analisis menunjukan bahwasanya jumlah ketersediaan air terhadap kebutuhan air di DAS Deli dapat dikatakan surplus dalam kurun waktu satu tahun, water balanced tertinggi pada Bulan September pertengahan pertama sebesar 43,526 m3/detik. Potensi defisit atau kekurangan air terjadi pada Bulan Maret pertengahan pertama (water balanced-1,425 m3/detik) sehingga perlu dilakukan penanganan dalam menanggulangi defisit air tersebut oleh stakeholder atau pemerintah.
\end{abstract}

Kata kunci : ketersediaan air, kebutuhan, neraca air

\section{PENDAHULUAN}

Perkembangan wilayah di suatu daerah akan mengakibatkan kebutuhan air terus mengalami peningkatan seiring dengan bertambahnya laju pertumbuhan penduduk. Kebutuhan pangan dan aktivitas penduduk sangat erat kaitannya dengan kebutuhan akan air. Tuntutan kebutuhan tersebut tidak dapat dihindari, tetapi haruslah diprediksi dan direncanakan pemanfaatannya sebaik mungkin. Kecenderungan yang sering terjadi adalah adanya ketidakseimbangan antara ketersediaan dan kebutuhan air. Untuk mencapai keseimbangan antara kebutuhan air dan ketersediaan air di masa mendatang, diperlukan 
upaya pengkajian komponen-komponen kebutuhan air, serta efisiensi penggunaan air. Penelitian tentang water balanced di beberapa lokasi di Indonesia sudah banyak dilakukan antara lain oleh Alitu, Labdul, dan Adam (2012); Kansil, Glend Randy.Dkk. (2015); Narulita (2017); Sari, Indra Kusuma. Dkk. (2013); dan Zulkipli, dkk. (2012).

Daerah Aliran Sungai Deli adalah salah satu sumber air utama terhadap kebutuhan air di Kota Medan dan Kabupaten Deli Serdang. Kebutuhan air yang digunakan yaitu kebutuhan air irigasi, air minum, dan industri (PDAM, 2012). Potensi air di DAS Deli pada saat ini sudah harus diperhitungkan kembali untuk dapat memenuhi kebutuhan air di masa mendatang dikarenakan jumlah debit diprediksi sudah mengalami penurunan semenjak tahun 2000 sampai 2013 (BWSSII \& Bappeda Provsu, 2013). Kondisi ini diakibatkan dari kondisi tata guna lahan di sekitar DAS Deli di bagian hulu, tengah, dan hilir sudah mengalami kerusakan yang signifikan sehingga limpasan air dari curah hujan tidak seluruhnya dapat ditampung dan disimpan dalam tanah untuk dapat dipergunakan sebagai cadangan air di musim kering (Jaya dan Hariatama, 2012).

Oleh sebab itu maka studi atau penelitian ini perlu dilakukan untuk dapat memberikan informasi mengenai neraca air di DAS Deli antara potensi ketersediaan air di masa yang akan datang dengan kebutuhan airnya sehingga hal ini dapat menjadi salah satu masukan dan bahan dasar atau awal untuk mengetahui kondisi jumlah kelebihan air dan kekurangan air di Kota Medan dan Kabupaten Deli Serdang yang memanfaatkan air dari DAS Deli.

\section{STUDI LITERATUR}

\subsection{Ketersediaan Air}

Ketersediaan air dalam pengertian sumber daya air pada dasarnya berasal dari air hujan (atmosferik), air permukaan dan air tanah. Hujan yang jatuh di atas permukaan pada suatu Daerah Aliran Sungai (DAS) atau Wilayah Sungai (WS) sebagian akan menguap kembali sesuai dengan proses iklimnya, sebagian akan mengalir melalui permukaan dan sub permukaan masuk ke dalam saluran, sungai atau danau dan sebagian lagi akan meresap jatuh ke tanah sebagai pengisian kembali (recharge) pada kandungan air tanah yang ada (Jaya \& Barly, 2016).

Ketersediaan air yang merupakan bagian dari fenomena alam, sering sulit untuk diatur dan diprediksi dengan akurat. Hal ini karena ketersediaan air mengandung unsur variabilitas ruang (spatial variability) dan variabilitas waktu (temporal variability) yang sangat tinggi. Konsep siklus hidrologi adalah bahwa jumlah air di suatu luasan tertentu di hamparan bumi dipengaruhi oleh masukan (input) dan keluaran (output) yang terjadi. Jumlah aliaran ketersediaan air secara hidrologi dari suatu wilayah dapat ditulis sebagai berikut:

$$
P=(R+G+E+T)-\Delta S
$$

Di mana: $\mathrm{P}$ adalah presipitasi (hujan), $\mathrm{R}$ adalah aliran permukaan, $\mathrm{G}$ adalah air tanah, $\mathrm{E}$ adalah evaporasi, $T$ adalah transpirasi, dan $\Delta \mathrm{S}$ adalah perubahan simpanan. Persamaan inilah yang dikenal sebagai persamaan dasar hidrologi.

\subsection{Kebutuhan Air}

Kebutuhan air adalah kebutuhan air yang digunakan dalam menunjang segala kegiatan manusia meliputi air bersih domestik dan non domestik, air irigasi baik pertanian maupun perikanan, dan air untuk penggelontoran kota. Kebutuhan air domestik sangat ditentukan oleh jumlah penduduk dan konsumsi perkapita. Kecenderungan populasi dan sejarah 
populasi dipakai sebagai dasar perhitungan kebutuhan air domestik terutama dalam penentuan laju pertumbuhan. Laju pertumbuhan ini juga tergantung dari rencana pengembangan dari tata ruang kabupaten. Kebutuhan air non domestik meliputi pemanfaatan komersial, kebutuhan institusi dan kebutuhan industri. Kebutuhan air komersil untuk suatu daerah cenderung meningkat sejalan dengan peningkatan penduduk dan perubahan tata guna lahan. Kebutuhan ini bisa mencapai $20 \%$ sampai $25 \%$ dari total suplai produksi air (Suripin, 2001).

\subsection{Daerah Aliran Sungai}

Daerah aliran sungai (DAS) sering juga disebut sebagai daerah tangkapan air yang dihulunya dibatasi oleh punggung-punggung gunung ataupun bukit, di mana air hujan yang jatuh di seluruh daerah tangkapan air tersebut beserta air tanahnya akan mengalir menuju sungai utama pada suatu titik outlet yang ditinjau (Triatmodjo, 2008). Undang-undang No.7 tahun 2004 pasal 1 menyatakan bahwa DAS adalah suatu wilayah daratan yang merupakan satu kesatuan dengan sungai dan anak-anak sungainya yang berfungsi menampung, menyimpan dan mengalirkan air yang berasal dari curah hujan ke danau atau ke laut secara alami yang batas di darat merupakan pemisah topografis dan batas di laut sampai dengan daerah perairan yang masih terpengaruh aktivitas daratan.

\subsection{Neraca Air (Water Balanced)}

Neraca air atau keseimbangan air (water balanced) adalah besarnya jumlah suatu aliran yang masuk dan keluar dari suatu sistem. Sistem tersebut dapat berupa suatu wilayah sungai atau Daerah Aliran Sungai yang mengalirkan air dari titik hulu sebagai inlet sampai ke hilir sebagai outlet. Debit aliran yang masuk dari inlet akan dimanfaatkan sepanjang Daerah Aliran Sungai untuk memenuhi kebutuhan air di sekitar das tersebut. Kebutuhan air dimanfaatkan oleh manusia sebagai air bersih, air minum, air irigasi, dan industri. Lokasilokasi titik pengambilan sumber air dari hulu sampai hilir sepanjang sungai yang dimanfaatkan sebagai kebutuhan air dapat diartikan sebagai alokasi air. Jadi hubungan ketersediaan air dengan kebutuhan air atau alokasi air dapat dirumuskan sebagai berikut

Neraca air $=$ Ketersediaan air - Kebutuhan air (alokasi air)

Dalam hal ini neraca air dapat memberikan kesimpulan dari hasil pengurangan ketersediaan air dengan kebutuhan air. Kelebihan air akan terjadi jika nilai neraca air memberikan hasil positif tetapi jika nilai neraca air memberikan hasil negatif maka hal ini akan mengakibatkan kekeringan atau kekritisan air (Asdak, C.,1995).

\section{METODOLOGI PENELITIAN}

\subsection{Metode Penelitian}

Penelitian dilakukan secara eksploratif kuantitatif dan kualitatif. Data-data penelitian diolah secara kuantitatif menggunakan persamaan-persamaan yang relevan dan hasilnya dijelaskan secara kualitatif. Kemudian kesimpulan diambil secara induktif yang artinya poin-poin pengamatan lapangan dan analisis data akan menghasilkan keseimbangan air atau neraca air di DAS Deli.

\subsection{Data Penelitian}

Data penelitian dapat dibagi menjadi 2 kelompok yaitu: 
a) Data primer adalah data debit di DAS Deli.

b) Data sekunder adalah data curah hujan bulanan dari stasiun penakar curah hujan di DAS Deli, data klimatologi, data jumlah penduduk, data alokasi air di DAS Deli, dan data laporan pendukung.

\subsection{Lokasi Penelitian}

Lokasi pengamatan penelitian meliputi Daerah Aliran Sungai (DAS) Sungai Deli khususnya yang mengalir dari hulu ke hilir yang melewati Kabupaten Deli Serdang sebahagian di bagian hulu dan Kota Medan di bagian hilir. Adapun lokasi penelitian ditampilkan pada Gambar 1.

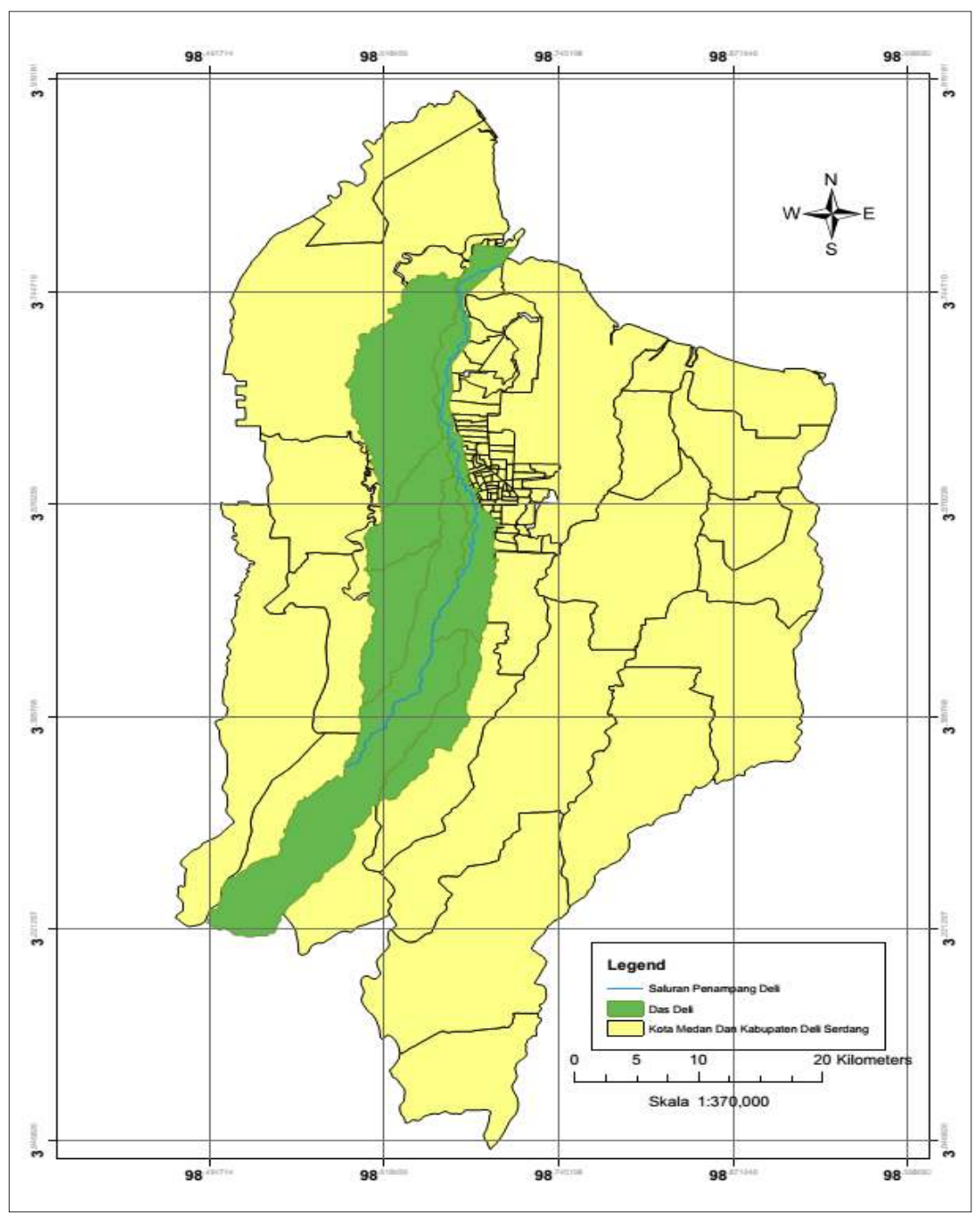

Gambar 1. Lokasi Penelitian

\subsection{Proses Studi Penelitian}

Proses studi penelitian analisis ketersediaan air terhadap kebutuhan air di DAS Deli dalam penelitian ini diperlihatkan pada Gambar 2. 


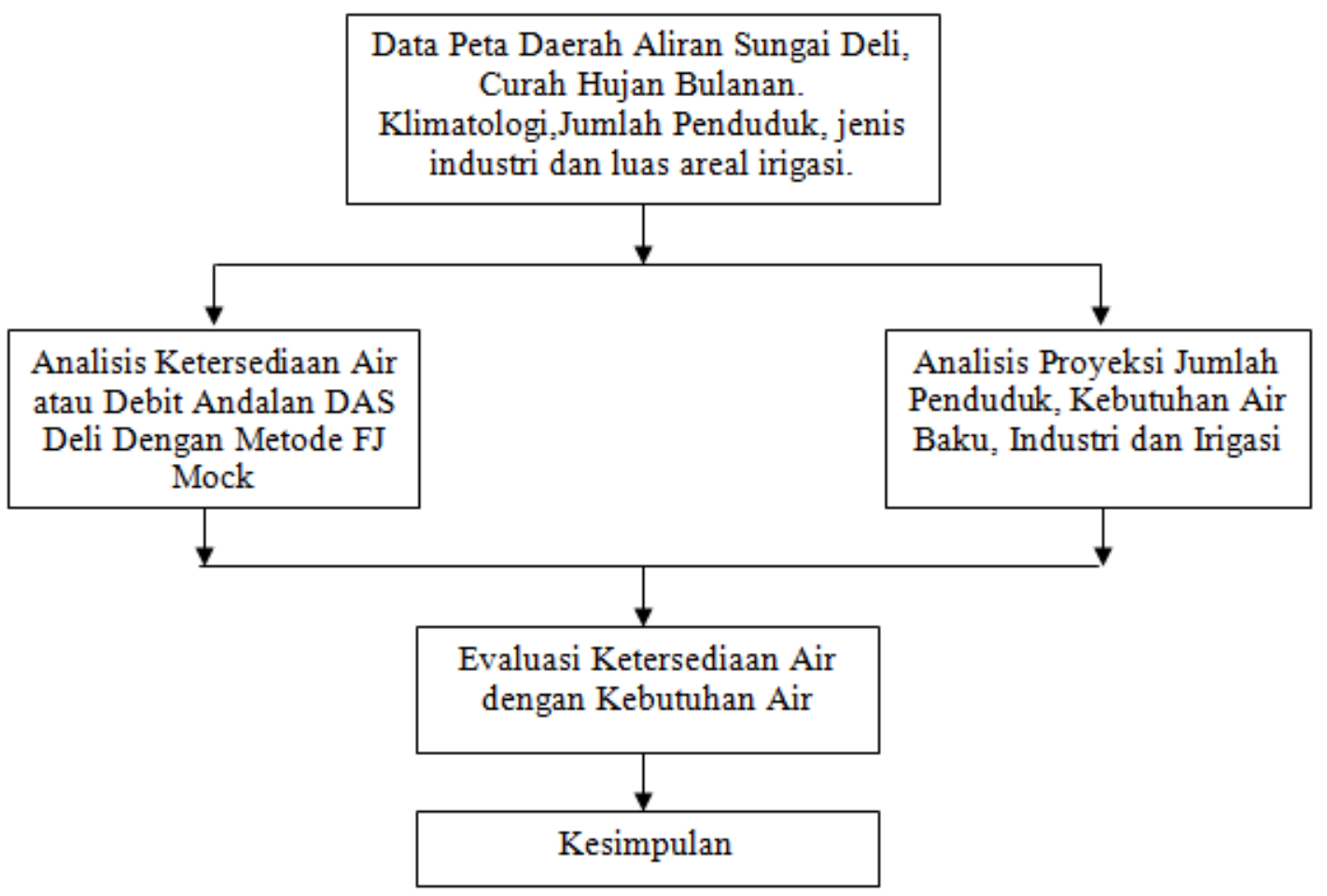

Gambar 2. Flowchart Tahapan Studi

\section{HASIL DAN PEMBAHASAN}

\subsection{Analisis Ketersediaan Air}

Analisis debit andalan (Jumlah ketersediaan air) dilakukan dengan metode empiris berdasarkan data curah hujan dan klimatologi menggunakan metode FJ MOCK. Data curah hujan yang digunakan yaitu curah hujan tengah bulanan yang mempengaruhi luas tangkapan Daerah Aliran Sungai Deli. Pos Stasiun curah hujan yang mempengaruhi luas tangkapan Daerah Aliran Sungai Deli adalah Stasiun Sampali, Stasiun Tuntungan, dan Stasiun Patumbak. Potensi ketersediaan air dianalisis berdasarkan probabilitas kejadian dengan kurun waktu tertentu yang dinyatakan dalam persen sehingga dalam menganalisis antara ketersediaan air dengan kebutuhan air dapat diperoleh ketersediaan air minimum yang dapat dimanfaatkan untuk memenuhi kebutuhan air baik itu air baku, irigasi, dan industri. Hasil analisa debit andalan tengah bulanan Daerah Aliran Sungai Deli ditampilkan pada Tabel 1.

Hasil analisis debit andalan dengan menggunakan Metode FJ MOCK menunjukan bahwasanya besar potensi ketersediaan air Daerah Aliran Sungai Deli dengan kejadian probabilitas $80 \%$ yaitu berada diantara $6.18 \mathrm{~m}^{3} /$ det $\mathrm{s} / \mathrm{d} 50 \mathrm{~m}^{3} /$ det. Perubahan probabilitas ketersediaan air secara grafik dapat ditampilkan pada Gambar 3. 
Tabel 1. Hasil Analisis Debit Andalan Tengah Bulanan Daerah Aliran Sungai Deli

\begin{tabular}{|c|c|c|c|c|c|c|c|c|c|c|c|c|c|c|c|c|c|c|c|c|c|c|c|c|}
\hline \multirow[t]{2}{*}{ Probabilitas (\%) } & \multicolumn{2}{|c|}{ Januari } & \multicolumn{2}{|c|}{ Februari } & \multicolumn{2}{|c|}{ Maret } & \multicolumn{2}{|c|}{ April } & \multicolumn{2}{|c|}{ Mei } & \multicolumn{2}{|c|}{ Juni } & \multicolumn{2}{|c|}{ Juli } & \multicolumn{2}{|c|}{ Agustus } & \multicolumn{2}{|c|}{ September } & \multicolumn{2}{|c|}{ Oktober } & \multicolumn{2}{|c|}{ Nopember } & \multicolumn{2}{|c|}{ Desember } \\
\hline & I & II & $\mathrm{I}$ & II & $\mathrm{I}$ & II & I & II & $\mathrm{I}$ & II & $\mathrm{I}$ & II & I & II & I & II & I & II & $\mathrm{I}$ & II & I & II & & II \\
\hline $10 \%$ & 48.64 & \begin{tabular}{|l|l|} 
\\
\end{tabular} & 50.92 & 60.04 & 91.78 & 108.00 & 70.06 & 64.52 & 74.91 & |24.93 & 51.57 & 55.97 & 79.98 & 70.56 & 83.25 & \begin{tabular}{|l|}
99,71 \\
\end{tabular} & \begin{tabular}{|l|}
86.29 \\
\end{tabular} & 95.99 & 07.749 & 99.428 & $83.80 \mathrm{G}$ & \begin{tabular}{|l|l|l|}
99.66 & 92 \\
\end{tabular} & $92.34 \quad 11$ & 106.30 \\
\hline $20 \%$ & & 1.05 & 34.73 & 52.11 & 59.77 & 70.03 & 54.35 & 62.86 & 55.16 & $(10.45$ & 48.67 & 32.39 & 43.59 & 66.95 & 75.19 & \begin{tabular}{|l|}
61.09 \\
\end{tabular} & 80.48 & 89.67 & \begin{tabular}{|l|l|}
79.49 & 9 \\
\end{tabular} & 99.106 & 68.74 .5 & \begin{tabular}{|l|l}
58.68 & 72 \\
\end{tabular} & 72.21 & 93.14 \\
\hline $30 \%$ & 2.90 & 33.11 & 32.81 & 40.26 & 46.74 & 56.55 & 47.25 & 62.29 & 48.01 & 62.96 & 42.30 & 29.36 & 38.96 & 58.71 & 70.02 & 53.03 & \begin{tabular}{|l|l|}
74.12 & 8 \\
\end{tabular} & 85.087 & 77.269 & 90.736 & 64.025 & \begin{tabular}{|l|l|}
57.90 & 6 \\
\end{tabular} & 61.23 & 60 \\
\hline $40 \%$ & 42.76 & 29.56 & 30.76 & 25.58 & 46.53 & 34.82 & 44.40 & 43.90 & 47.49 & 59.48 & 41.67 & 28.96 & 38.39 & 48.95 & 58.01 & 50.88 & 66.00 & 59.17 & 70.578 & $84.85 \quad 5$ & $53.48 \quad 5$ & \begin{tabular}{|l|l|l} 
\\
\end{tabular} & 54.30 & 59.06 \\
\hline $50 \%$ & 33.90 & 29.33 & 20.40 & 24.97 . & 31.21 & 33.68 & 30.59 & 26.36 & 42.52 & 57.49 & 38.69 & 27.13 & 37.45 & 40.76 & 53.03 & 50.45 & \begin{tabular}{|l|l}
58.69 & 5 \\
\end{tabular} & 55.85 & \begin{tabular}{|l|l|}
$66.51 \quad 6$ \\
\end{tabular} & $67.56 \quad 4$ & 48.774 & \begin{tabular}{|l|l|}
46.01 & 46 \\
\end{tabular} & 46.32 & 42.52 \\
\hline $60 \%$ & 3.23 & 26.73 & 12.48 & 24.22 & 20.04 & 22.64 & 26.45 & 20.44 & 42.11 & 42.88 & 38.20 & 25.80 & 29.47 & 36.69 & 33.04 & 49.65 & $\begin{array}{l}53.85 \\
\end{array}$ & 52.78 & $\begin{array}{ll}60.24 & 5 \\
\end{array}$ & 58.63 & $\begin{array}{lll}47.334 \\
\end{array}$ & \begin{tabular}{|l|l|}
45.28 & 4 \\
\end{tabular} & 44.83 & 40.60 \\
\hline $70 \%$ & 30.27 & 25.60 & 11.34 & \begin{tabular}{|l|}
20.49 \\
\end{tabular} & 16.59 & 21.07 & 26.20 & 14.21 & 31.82 & 38.63 & 29.96 & 22.38 & 22.49 & 36.48 & 21.40 & 40.59 & \begin{tabular}{|l|l}
53.66 & 3 \\
\end{tabular} & 37.34 .5 & \begin{tabular}{|l|l|}
52.10 & 3 \\
\end{tabular} & 38.873 & \begin{tabular}{l|l|}
38.32 & 4 \\
\end{tabular} & \begin{tabular}{|l|l|}
43.23 & 29 \\
\end{tabular} & 29.00 & 30.27 \\
\hline $80 \%$ & 28.63 & 18.92 & 10.47 & 19.31 & 6.18 & 19.04 & 25.24 & 13.72 & 31.54 & 32.71 & 24.82 & 19.55 & 18.743 & 30.48 & 17.96 & 32.68 & 50.002 & 29.18 & \begin{tabular}{|l|l|}
42.52 & 3. \\
\end{tabular} & 32.973 & \begin{tabular}{rl|}
34.293 & 3 \\
\end{tabular} & \begin{tabular}{|l|l}
39.03 & 23 \\
\end{tabular} & 23.09 & 27.56 \\
\hline $90 \%$ & 20.27 & 15.89 & 6.19 & 12.87 & 4.52 & 13.48 & 23.27 & 13.00 & 28.54 & 25.02 & 18.16 & 12.58 & \begin{tabular}{ll|l}
$15.76 \quad 2$ \\
\end{tabular} & 21.23 & 17.17 & 28.78 & \begin{tabular}{|l|l|l|l|l|}
43.00 & 2 \\
\end{tabular} & 26.953 & \begin{tabular}{l|l}
34.01 & 31 \\
\end{tabular} & 30.732 & \begin{tabular}{ll|l}
$29.74 \quad 2$ \\
\end{tabular} & \begin{tabular}{|l|l|}
24.00 & 11 \\
\end{tabular} & 19.56 & 25.72 \\
\hline $100 \%$ & 17.83 & \begin{tabular}{|l|}
7.99 \\
\end{tabular} & 2.32 & $\begin{array}{l}6.49 \\
\end{array}$ & \begin{tabular}{l|l|}
3.12 \\
\end{tabular} & 12.77 & 17.31 & 9.35 & 17.22 & 19.76 & 8.35 & 12.29 & 13.481 & 19.83 & 0.69 & \begin{tabular}{|l|}
6.68 \\
\end{tabular} & 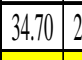 & 20.783 & 32.052 & 27.742 & \begin{tabular}{|l|l|l|}
21.03 & 1 \\
\end{tabular} & \begin{tabular}{|l|l|}
13.69 & 6 \\
\end{tabular} & 6.11 & 20.89 \\
\hline Rata-Rata & 34.653 & 26.791 & 21.2432 & 28.632 .3 & $32.648 \mid 3$ & 39.207 . & 36.5103 & 33.066 & 41.9315 & 58.2313 & $34.238 \mid$ & 26.6413 & $33.832 \mid 4$ & $43.063 \mid 4$ & & $|47.354| 6$ & $\begin{array}{ll}60.139 & 5 . \\
\end{array}$ & 55.2806 & 62.24963 & 63.0604 & 48.95247 & & 44.9005 & 50.659 \\
\hline
\end{tabular}

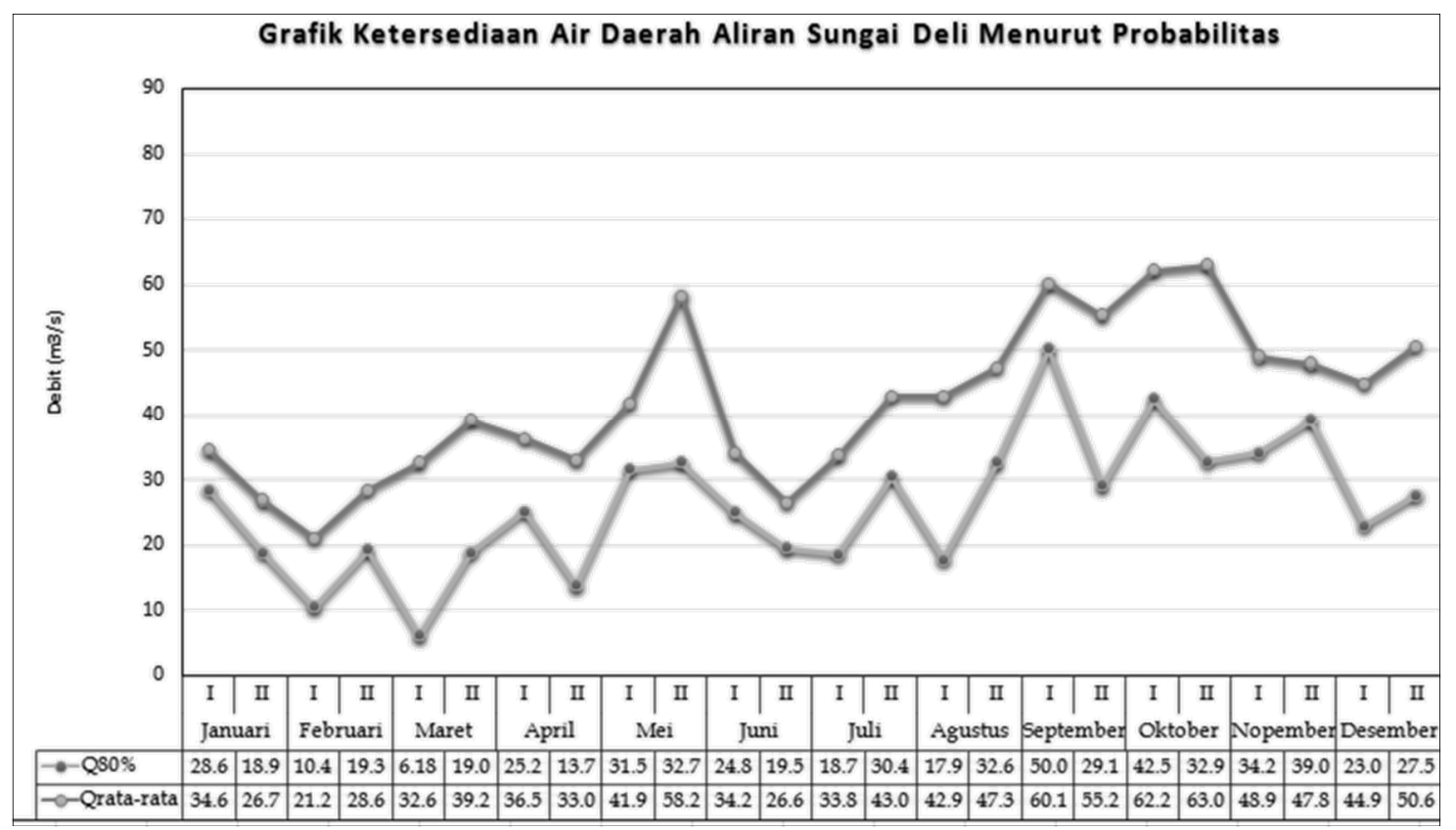

Gambar 3. Grafik Ketersediaan Air Probabilitas 80\% dan 50\% Daerah Aliran Sungai Deli

\subsection{Analisis Kebutuhan Air}

Analisis kebutuhan air bertujuan untuk mengetahui besarnya debit yang dimanfaatkan dari ketersediaan air di dalam cakupan wilayah Daerah Aliran Sungai Deli. Kebutuhan air dapat berupa kebutuhan air irigasi, air baku, dan industri sesuai dengan titik pengambilan yang berasal dari hulu sampai hilir sesuai dengan alokasi air. Titik titik pengambilan kebutuhan air atau alokasi air di Daerah Aliran Sungai Deli ditampilkan pada Gambar 4.

Dari Gambar 4 diperoleh lokasi pengambilan di tiap titik kebutuhan air sepanjang cakupan Daerah Aliran Sungai Deli baik itu irigasi, air baku, dan industri. Analisis kebutuhan air irigasi dihitung berdasarkan pola tanam yang dilakukan selama masa pengolahan lahan maupun masa tanam dalam satu tahun berdasarkan dengan jenis tanaman dan kondisi tanah. Analisis kebutuhan air baku IPA Deli Tua dihitung berdasarkan proyeksi jumlah penduduk yang dilayani dengan standar kebutuhan air per orang. Kebutuhan Industri di 
daerah hilir Daerah Aliran Sungai Deli adalah industri yang bergerak di bidang pengolahan bahan baku. Industri pengolahan bahan baku di bagian hilir Daerah Aliran Sungai Deli termasuk kepada jenis industri sedang dengan besar kebutuhan air industri 97000 l/hari atau setara dengan $0.001 \mathrm{~m}^{3} /$ det.

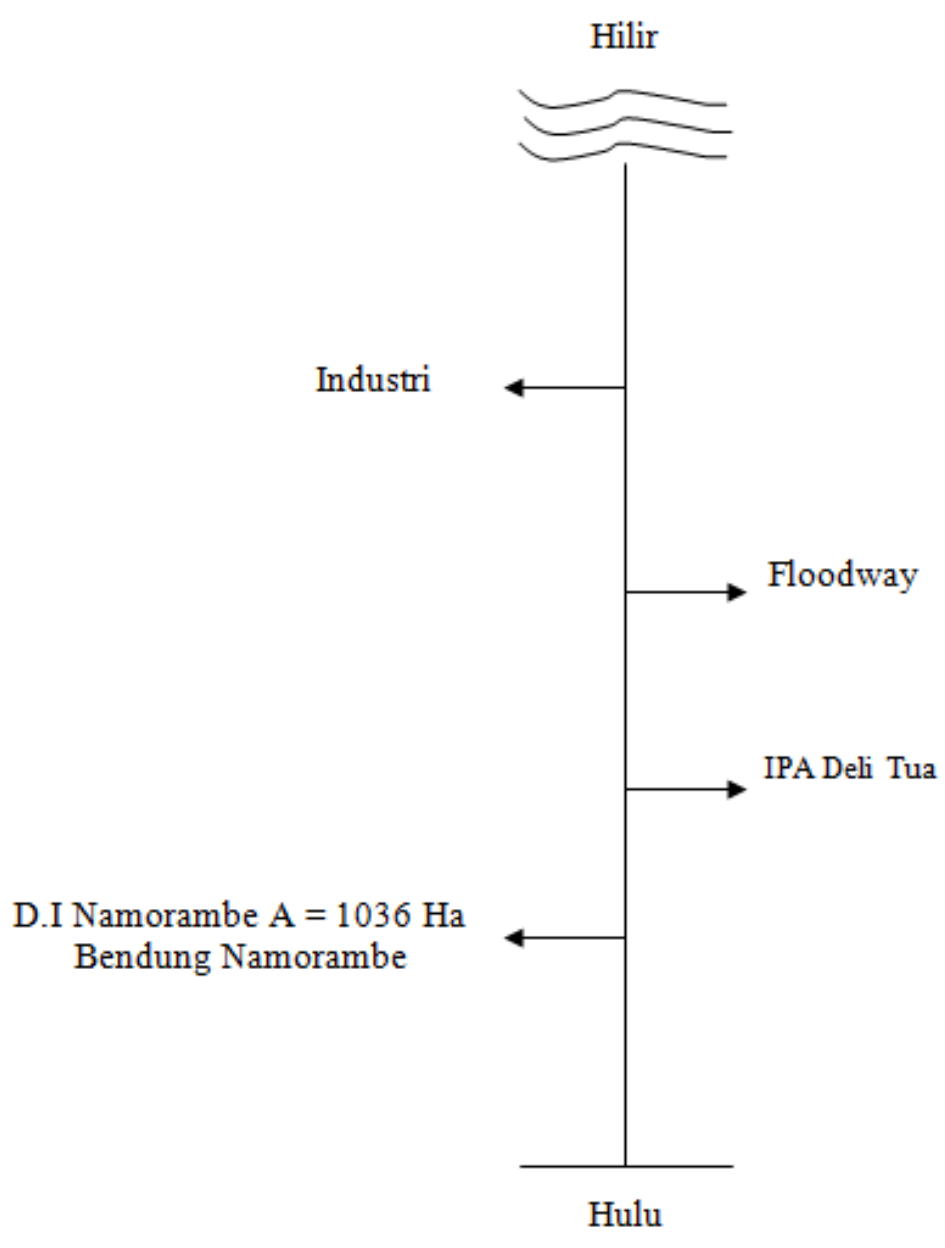

Gambar 4. Titik Pengambilan atau Alokasi Air Eksisting Daerah Aliran Sungai Deli

\subsection{Analisis Keseimbangan Air (Water Balanced)}

Analisis keseimbangan air adalah selisih antara jumlah ketersediaan air dengan kebutuhan air di sepanjang cakupan Daerah Aliran Sungai Deli. Hasil selisih antara jumlah ketersediaan air dengan kebutuhan air dianalisis menurut waktu yang dimanfaatkan baik dalam tengah bulanan maupun bulanan berdasarkan titik pengambilan atau alokasi air yang telah ditentukan. Rekapitulasi hasil Analisis keseimbangan air di Daerah Aliran Sungai Deli selama satu tahun ditampilkan pada Tabel 2.

Tabel 2. Rekapitulasi Analisa Keseimbangan Air Terhadap Alokasi Air DAS Deli Selama Satu Tahun

\begin{tabular}{llllll}
\hline No & Bulan & Total Inflow & Total Outflow & Water Balanced & Kondisi \\
\cline { 3 - 5 } & & $\mathrm{m3} /$ det & $\mathrm{m3} /$ det & $\mathrm{m} 3 /$ det & \\
\hline 1 & Januari I & 30,632 & 6,556 & 24,076 & Surplus \\
\hline 2 & Januari II & 18,921 & 6,77 & 12,151 & Surplus \\
\hline
\end{tabular}




\begin{tabular}{|c|c|c|c|c|c|}
\hline \multirow[t]{2}{*}{ No } & \multirow[t]{2}{*}{ Bulan } & \multirow{2}{*}{$\begin{array}{l}\text { Total Inflow } \\
\text { m3/det }\end{array}$} & \multirow{2}{*}{$\begin{array}{l}\text { Total Outflow } \\
\text { m3/det }\end{array}$} & \multirow{2}{*}{$\begin{array}{l}\text { Water Balanced } \\
\mathrm{m} 3 / \text { det }\end{array}$} & \multirow[t]{2}{*}{ Kondisi } \\
\hline & & & & & \\
\hline 3 & Februari I & 10,471 & 6,915 & 3,556 & Surplus \\
\hline 4 & Februari II & 19,272 & 6,646 & 12,626 & Surplus \\
\hline 5 & Maret I & 6,179 & 7,604 & $-1,425$ & Defisit \\
\hline 6 & Maret II & 19,037 & 7,357 & 11,68 & Surplus \\
\hline 7 & April I & 25,236 & 6,958 & 18,278 & Surplus \\
\hline 8 & April II & 13,721 & 7,153 & 6,568 & Surplus \\
\hline 9 & Mei I & 31,541 & 6,7 & 24,841 & Surplus \\
\hline 10 & Mei II & 32,71 & 6,612 & 26,098 & Surplus \\
\hline 11 & Juni I & 25,421 & 6,518 & 18,903 & Surplus \\
\hline 12 & Juni II & 19,55 & 6,528 & 13,022 & Surplus \\
\hline 13 & Juli I & 18,74 & 6,706 & 12,034 & Surplus \\
\hline 14 & Juli II & 30,475 & 6,706 & 23,769 & Surplus \\
\hline 15 & Agustus I & 17,954 & 7,362 & 10,592 & Surplus \\
\hline 16 & Agustus II & 32,679 & 7,065 & 25,614 & Surplus \\
\hline 17 & September I & 49,997 & 6,471 & 43,526 & Surplus \\
\hline 18 & September II & 29,178 & 6,882 & 22,296 & Surplus \\
\hline 19 & Oktober I & 42,969 & 6,45 & 36,519 & Surplus \\
\hline 20 & Oktober II & 32,303 & 6,541 & 25,762 & Surplus \\
\hline 21 & November I & 34,292 & 6,706 & 27,586 & Surplus \\
\hline 22 & November II & 39,004 & 6,706 & 32,298 & Surplus \\
\hline 23 & Desember I & 23,094 & 6,706 & 16,388 & Surplus \\
\hline 24 & Desember II & 27,561 & 6,706 & 20,855 & Surplus \\
\hline
\end{tabular}

Hasil analisis di atas menunjukan bahwasanya secara umum jumlah ketersediaan air di Daerah Aliran Sungai Deli cukup dalam memenuhi kebutuhan air dalam kurun waktu satu tahun tetapi khusus pada Bulan Maret pertengahan I jumlah ketersediaan air tidak dapat memenuhi jumlah kebutuhan air sehingga hal ini dapat menjadi peringatan bagi stakeholder atau pemerintah dalam menanggulangi jumlah ketersediaan air yang menimbulkan potensi kekurangan air atau defisit air.

\section{SIMPULAN DAN SARAN}

Hasil dari analisis keseimbangan air atau water balanced di Daerah Aliran Sungai Deli menunjukkan bahwasanya jumlah ketersediaan air terhadap jumlah kebutuhan air dapat memenuhi dalam kurun waktu satu tahun. Potensi kekurangan air atau defisit air terjadi pada Bulan Maret pertengahan pertama sehingga perlu dilakukan solusi dalam penanganannya. Ada beberapasaran yang perlu dilakukan untuk mengatasi kekurangan air yang terjadi di Daerah Aliran Sungai Deli yaitu perlu dilakukan perbaikan terhadap kondisi tata guna lahan di sepanjang Daerah Aliran Sungai Deli. Salah satunya dengan melakukan konservasi daerah aliran sungai secara menyeluruh dimulai dari bagian hulu sampai hilir. Konservasi daerah aliran sungai dapat dilakukan dengan merencanakan tampungan air dan revitalisasi tata guna lahan yang telah dirusak, salah satunya dengan penanaman hutan gundul dan pemeliharaan hutan lindung didukung oleh kebijakan atau peraturan yang tegas dari Pemerintah atau Instansi terkait. 


\section{UCAPAN TERIMAKASIH}

Penulis mengucapkan terima kasih kepada Lembaga Penelitian dan Pengabdian Kepada Masyarakat Universitas Muhammadiyah Sumatera Utara yang telah membiayai penelitian ini.

\section{DAFTAR PUSTAKA}

Alitu, Labdul, dan Adam. (2012). Analisis Keseimbangan Air Daerah Aliran Sungai Bolango di Boidu. Universitas Gorontalo. Gorontalo.

Asdak, C. (1995). Hidrologi dan Pengelolaan Daerah Aliran Sungai. Gadjah Mada University Press, Yogyakarta

BWSSII dan Bappeda Provsu. (2013). Rencana Pengelolaan DAS Terpadu Deli. Medan.

Hammer, W.I. (1981). Soil Conservation Consultant Report Center for Soil Research. LPT Bogor. Indonesia.

Jaya dan Hariatama. (2012). Analisis Optimalisasi Pola Tanam Daerah Irigasi Namorambe Kabupaten Deli Serdang. USU, Medan.

Jaya dan Barly. (2016). Analisis Ketersediaan Air Terhadap Kebutuhan Air Pada DAS Percut Untuk Memenuhi Kebutuhan Air Bersih Di Kabupaten Deli Serdang. USU, Medan.

Kansil, Glend Randy. Dkk. (2015). Analisis Neraca Air Sungai Akembuala di Kota Tahuna Kabupaten Sangihe, Jurnal Sipil Statik, Vol. 3 No. 7, 503 - 514, ISSN 2337-6732.

Narulita. (2017). Pendugaan Neraca Air Spasial untuk Evaluasi Ketersediaan Sumber daya Air Studi Kasus: Daerah Aliran Sungai Cerucuk, Pulau Belitung, Jurnal Teknologi Lingkungan, Vol. 18, No. 1, 120-129.

PDAM. (2012). Alokasi Air Daerah Aliran Sungai Deli. Medan.

Sari, Indra Kusuma. Dkk. (2013). Analisa Ketersediaan dan Kebutuhan Air Pada DAS Sampean, dalam jurnal: Teknik Sipil , Vol. 2 No.6, 57-68. ISSN 2407-7332.

Suripin. (2001). Pelestarian Sumber Daya Tanah Dan Air. Andi Offset, Yogyakarta.

Triatmodjo, B. (2008). Hidrologi Terapan. Beta Offset, Yogyakarta.

Zulkipli, dkk. (2012). Analisa Neraca Air Permukaan DAS Renggung untuk Memenuhi Kebutuhan Air Irigasi dan Domestik. Jurnal Teknik Pengairan. (Online). Vol.3(2) 